\title{
Fatty acids composition of fruits of selected Central European sedges, Carex L. (Cyperaceae)
}

\author{
By Anna Bogucka-Kocka ${ }^{a}$ and Magdalena Janyszek ${ }^{b^{*}}$ \\ ${ }^{a}$ Department of Pharmaceutical Botany, Medical University, Lublin, Poland, \\ ${ }^{b}$ Department of Botany, Poznan University of Life Sciences Poznań, Poland
}

( ${ }^{\star}$ Corresponding author:carexmag@ @au.poznan.pl)

\section{RESUMEN}

Composición de ácidos grasos de frutos de juncos (Carex L., Cyperaceae) seleccionados de Europa Central.

Los ácidos grasos de frutos de 13 especies de juncos (Carex L., Cyperaceae) fueron analizados. El contenido de aceite en los frutos de juncos estudiados vario desde un 3.73 a un $46.52 \%$. En los aceites de los frutos estudiados fueron identificados 14 ácidos grasos diferentes. Los principales ácidos grasos insaturados fueron los ácidos linoleico, $\alpha$-linolenico, oleico, n-7 palmitoleico, n-9 palmitoleico, octadecenoico y eicosanoico. Los siguientes ácidos grasos fueron encontrados en mayor cantidad: ácido linoleico, ácido oleico, ácido $\alpha$-linolenico, y ácido palmítico. Basado en la composición de ácidos grasos, las especies estudiadas pueden ser divididas en dos grupos. El primer grupo (C. flava, C. pseudocyperus, $C$. riparia, $C$. leporina) es una muy buena fuente de ácido linoleico. El segundo grupo, que incluye las especies restantes, es una buena fuente de ácido $\alpha$-linolenico. Los contenidos más altos de ácido oleico fueron observados en $C$. vulpine. El material estudiado ha mostrado una baja concentración de ácidos grasos saturados, de entre los cuales el ácido palmítico fue el principal. El análisis de los resultados nos permite considerar que los frutos de las especies de plantas estudiadas se caracterizan por su alto contenido en ácidos grasos insaturados.

PALABRAS CLAVE: Carex - Composición de ácidos grasos - Fruto - Junco - Nueces.

\section{SUMMARY}

Fatty acids composition of fruits of selected Central European sedges (Carex L. Cyperaceae).

Fatty acids in the fruits of 13 sedge species (Carex L., Cyperaceae) were analyzed. The oil contents in the fruits of the studied sedges ranged from 3.73 and $46.52 \%$. In the studied fruit oils 14 different fatty acids were identified. The main unsaturated fatty acids were: linoleic, $\alpha$-linolenic, oleic, oleopalmitic n-7; oleopalmitic n-9, octadecenic, and eicosenoic acids. The following acids were found in the greatest quantities: linoleic, oleic, $\alpha$-linolenic and palmitic acids. Based on the fatty acid composition, studied taxa can be divided in two groups. The first group ( $C$. flava, C. pseudocyperus, C. riparia, C. leporina) is a very good source of linoleic acid. The second group, including the remaining species, is a good source of $\alpha$-linolenic acid. The highest oleic acid contents were observed in C. vulpina. The studied material has shown a low concentration of saturated fatty acids, among which palmitic acid was the main one.
Results of the analyses allow for the inclusion of the studied species among plants whose fruits are characterized by a high content of unsaturated fatty acids.

KEY-WORDS: Carex - Fatty acid composition - Fruit Nut-Sedge.

\section{INTRODUCTION}

Sedges (Carex L., Cyperaceae) represent one of the most common vascular plant groups in the world. They occur in very different habitat conditions, both in wet and moist locations such as peat bogs, fens, meadows and pasture communities as well as their peripheries. They also exist in dry and extremely dry habitats which include among others xerothermic and psammophilous grasslands. Many of these habitats constitute or may potentially constitute areas of agricultural use, for example as pastures for cattle. In spite of the fact that such diversified habitat types are dominated by the representatives of one genus and in spite of the high biocenotic importance of sedges, the practical utilization of these plants is not great. Only in some regions of the world, few species are used as fodder, or they are sown in meadow grass mixtures (i.e. Ingvason, 1969; Herman, 1970; Fox, 1991). However the results of an increasing number of studies on the chemical composition of sedges indicate high nutritive values. They include among others macro and microelements (e.g. Catling et al., 1994; Grzelak et al., 2005; Janyszek et al., 2005), flavonoids (Kukkonen, 1971; Manhrt, 1986), oligostilbenes (Suzuki et al., 1987; Kawabata et al., 1989; Hegnauer, 1986; Kurihara et al., 1990; Kawabata et al., 1991; Kurihara et al., 1991) alkaloids (Hegnauer, 1986), phenolic acids (Li, 1974; Bogucka-Kocka and Krzaczek, 2004), essential oils and saponins (Hegnauer, 1963).

Substances which also have a great importance in nutrition are fatty acids contained in the seed oils of many plant species which have been used since a long time ago in food and pharmaceutical industries as well as in the cosmetic industry. The unsaturated fatty acids are particularly valuable. They are indispensable for a correct metabolism, but, 
unfortunately, animals are not able to synthethize them by themselves. Plant species which possess abundant amounts of this type of fatty acids include e.g.: Olea europaea L., Helianthus annuus L., Zea mays L., Oenothera biennis L., Arachis hypogaea L., Juglans regia L., Linum usitatissimum L. and Brassica napus L.

The analysis of fatty acids in the representatives of the Carex genus is not frequent. The few existing studies carried out in the generative organs of sedge nutlets were performed on only about a dozen species (Earle and Jones, 1962; Jones and Earle, 1966; Barclay and Earle, 1974; Egorova, 1999; Ahmad and Ansari, 1987) and only the percent of oil content was reported. Additionally, in the case of fruits, most of the earlier methods of analyses were based on hot extraction, which have currently been replaced by cold extraction. The use of the latter method protects fatty acids against oxygenation. On the other hand, other works dealing with this topic referred to fatty acids occurring in leaf structures and not producing any oil fractions (e.g. Ayaz and Olgun, 2000).

The main aim of the present work was the quantitative and qualitative analyses of the fatty acids occurring in the oil from fruits (nuts) of selected Carex species and the determination of selected species as a potential source of IUFA.

\section{MATERIALS AND METHODS}

\subsection{Plant material}

The study was conducted on representatives of 13 species of sedges which are comparatively widespread and relatively common in the Central European Netherlands. Representatives of the following species were studied: from the Vignea subgenus: Carex paniculata L., C. appropinquata Schum., C. diandra Schrank.; C. vulpina L., C. otrubae Podp.; C. contigua Hoppe. From the Carex subgenus: C. leporina L., C. rostrata Stokes; $C$. pseudocyperus L.; $C$. flava L; $C$. acuta L., C. nigra Reich, C. elata All. Systematics and nomenclature of the species have been accorded to Egorova (1999).

For each species, ripe utricles were collected from three different populations growing in the same types of phytocenoses. Plant material was sampled from natural sites from characteristic and most typical habitats and phytocenotic conditions for the given species (e.g. Janyszek et al., 2008; Janyszek and Jagodzinski, 2009). The specimens came from the territory of Poland. Plant material has been deposited in the Herbarium of Botany Department (POZNB) of Poznań University of Life Sciences (Poland).

The utricles were dried in natural conditions. After drying, the fruits were removed from the utricles. The nuts (fruits of the Carex), constituting the study material, were analyzed. Nuts were weighed, packed, kept in a cool dry room, and later ground into powder form with an electrical mill.

\subsection{Extraction of oil}

Fatty acids were obtained by cold hexane extraction from disintegrated fruits. Fatty acid fractions were taken using cold hexane. Disintegrated raw material was flooded with a 5-fold amount of hexane and it was macerated for $24 \mathrm{hr}$ at room temperature in the dark. After that time the samples were filtered and again they were flooded with an adequate amount of solvent. This procedure was repeated three times. Then, the extract was pooled, hexane was removed (vacuum rotary evaporation, $35^{\circ} \mathrm{C}$ ), and the extract was filled into glass ampoules and vacuum packed. These samples were stored at $-20^{\circ} \mathrm{C}$ until the time of analysis. Each analysis for each species was performed in three replicates which with 3 collected utricle populations for each taxon made 9 independent tests. Averaged values are reported (Tables 1, 2).

Fatty acid occurrences were determined in the analyzed samples by HR-GC methods. After standard methylation, fatty acid methyl esters were analyzed by a GC Agilent 6890 gas chromatograph equipped with a column RTX 2330 Restek 100 $\mathrm{m}$, calibre $0.25 \mathrm{~mm}$, temperature of injector port $240{ }^{\circ} \mathrm{C}$, in column $175^{\circ} \mathrm{C}$, in detector port $250^{\circ} \mathrm{C}$, carrier gas - helium 11/1 min., injection of split $1 \mu \mathrm{l} /$ $\mathrm{cm}^{3}$. Content percentage was estimated by internal normalization.

\subsection{Statistical Analysis}

The obtained results of the qualitative and quantitative fatty acid fractions were subject to cluster analysis by Ward's method using Statistica 6.0. The analyzed variables included standardized concentrations of the particular fatty acids. Mutual similarities of the particular species are presented in the dendrogram (Fig. 1).

\section{RESULTS AND DISCUSSION}

In the examined seed oil samples the occurrence of 14 fatty acids was confirmed (Tables 1,2$)$. In the studied Carex oils monounsaturated (MUFA) and polyunsaturated (PUFA) fatty acids predominated. In all studied species, linoleic, oleic, $\alpha$-linolenic (UNSAT) and palmitic acids (SAT) were found in the greatest quantities. From the point of view of nutrition physiology, the most important for a correct metabolism in the animal organism are PUFA. From this group of acids, linoleic and $\alpha$-linolenic acids were identified in the analyzed fruits. Both acids occur in significant amounts in the fruits of all analyzed taxa. Linoleic acid occurs in all studied species and it is the predominant compound in the majority of them. This acid is present in the greatest quantities (above 60\%) in C. flava (74.23\%), C. pseudocyperus $(72.61 \%)$, C. rostrata $(67.54 \%)$, and C. leporina $(64.87 \%)$ (Tables 1, 2). These species differ regarding the concentration of linoleic acid as compared with the other studied taxa. The concentration of this compound is also higher than 
Table 1

Percentage contents of fatty acids obtained from fruits of Carex L. from the Carex subgenus

\begin{tabular}{|c|c|c|c|c|c|c|}
\hline Fatty acid ${ }^{*}$ & C. rostrata & C. pseudocyperus & C. flava & C .acuta & C. nigra & C. elata \\
\hline C14:0* & $0.26 \pm 0.033$ & $0.15 \pm 0.020$ & $0.27 \pm 0.101$ & $0.71 \pm 0.049$ & $0.25 \pm 0.023$ & $0.44 \pm 0.081$ \\
\hline C16:0 & $5.43 \pm 0.174$ & $3.11 \pm 0.086$ & $4.75 \pm 0.111$ & $6.56 \pm 0.119$ & $6.07 \pm 0.051$ & $7.76 \pm 0.089$ \\
\hline $\mathrm{C} 16: 1 ; \Delta^{9}$ & 0 & $0.08 \pm 0.015$ & 0 & $0.17 \pm 0.050$ & $0.09 \pm 0.001$ & $0.28 \pm 0.028$ \\
\hline C16:1; $\Delta^{7}$ & $0.20 \pm 0.031$ & $0.03 \pm 0.010$ & $0.03 \pm 0.002$ & $0.20 \pm 0.070$ & 0 & $0.29 \pm 0.019$ \\
\hline C18:0 & $1.34 \pm 0.040$ & $0.90 \pm 0.021$ & $3.23 \pm 0.121$ & $2.70 \pm 0.055$ & $2.26 \pm 0.053$ & $3.31 \pm 0.014$ \\
\hline C18:1; $\Delta^{9}$ & $14.64 \pm 0.273$ & $18.19 \pm 0.326$ & $11.50 \pm 0.434$ & $15.79 \pm 0.913$ & $17.13 \pm 0.511$ & $15.90 \pm 0.546$ \\
\hline C18:1; $\Delta^{7}$ & $0.40 \pm 0.050$ & $0.40 \pm 0.051$ & $0.30 \pm 0.062$ & $0.37 \pm 0.041$ & $0.42 \pm 0.050$ & $0.39 \pm 0.012$ \\
\hline $\mathrm{C} 18: 2 ; \Delta^{9} \cdot \Delta^{12}$ & $67.54 \pm 1.036$ & $72.61 \pm 1.598$ & $74.23 \pm 1.878$ & $49.30 \pm 1.032$ & $46.34 \pm 0.381$ & $34.65 \pm 0.768$ \\
\hline $\mathrm{C} 20: 0$ & $1.20 \pm 0.091$ & $0.27 \pm 0.023$ & $0.80 \pm 0.091$ & $1.55 \pm 0.080$ & $0.76 \pm 0.024$ & $1.24 \pm 0.123$ \\
\hline $\mathrm{C} 18: 3 ; \Delta^{9} \cdot \Delta^{12} \cdot \Delta^{15}$ & $2.18 \pm 0.113$ & $0.51 \pm 0.023$ & $1.65 \pm 0.082$ & $14.06 \pm 0.324$ & $24.56 \pm 0.611$ & $32.49 \pm 0.560$ \\
\hline $\mathrm{C} 20: 1 ; \Delta^{3}$ & $0.22 \pm 0.021$ & $0.32 \pm 0.098$ & $0.33 \pm 0.060$ & $0.70 \pm 0.092$ & $0.25 \pm 0.021$ & $0.25 \pm 0.050$ \\
\hline $\mathrm{C} 22: 0$ & $0.31 \pm 0.039$ & $0.19 \pm 0.027$ & $0.96 \pm 0.022$ & $1.41 \pm 0.060$ & 0 & 0 \\
\hline $\mathrm{C} 22: 1 ; \Delta^{13}$ & $0.04 \pm 0.015$ & $0.04 \pm 0.030$ & $0.06 \pm 0.008$ & $0.65 \pm 0.060$ & $0.51 \pm 0.022$ & $0.57 \pm 0.024$ \\
\hline $\mathrm{C} 24: 0$ & $0.13 \pm 0.060$ & $0.19 \pm 0.021$ & $0.25 \pm 0.033$ & $0.61 \pm 0.032$ & 0 & $0.38 \pm 0.012$ \\
\hline SFA & $8.67 \pm 0.072$ & $4.81 \pm 0.033$ & $9.96 \pm 0.080$ & $13.54 \pm 0.066$ & $9.34 \pm 0.038$ & $13.11 \pm 0.064$ \\
\hline MUFA & $15.5 \pm 0.078$ & $19.06 \pm 0.088$ & $12.22 \pm 0.113$ & $17.88 \pm 0.204$ & $18.4 \pm 0.121$ & $17.68 \pm 0.113$ \\
\hline PUFA & $69.72 \pm 0.575$ & $73.12 \pm 0.811$ & $75.88 \pm 0.950$ & $66.36 \pm 0.678$ & $70.9 \pm 0.496$ & $67.14 \pm 0.664$ \\
\hline MUFA+PUFA & $85.22 \pm 0.220$ & $92.18 \pm 0.269$ & $88.1 \pm 0.361$ & $84.24 \pm 0.323$ & $89.3 \pm 0.228$ & $84.82 \pm 0.251$ \\
\hline SAT/UNSAT & 0.1 & 0.04 & 0.11 & 0.16 & 0.1 & 0.15 \\
\hline C18: $1 ; \Delta^{9} / \mathrm{C} 18: 2 ; \Delta^{9} \cdot \Delta^{12}$ & 0.21 & 0.25 & 0.15 & 0.36 & 0.4 & 0,46 \\
\hline Mass of samples (g) & 25.3 & 59.75 & 14.95 & 15.95 & 4.5 & 4,4 \\
\hline Quantity of oil (g) & 3.17 & 2.23 & 2.14 & 1.72 & 1.58 & 1,75 \\
\hline $\begin{array}{l}\text { Percentage } \\
\text { contents of oil }\end{array}$ & 12.53 & 3.73 & 14.31 & 10.78 & 35.11 & 39.97 \\
\hline
\end{tabular}

${ }^{*}$ C14:0 Myristic acid; C16:0 Palmitic acid; C16:1 $\Delta^{9}$ - Oleopalmitic acid; C16:1 $\Delta^{7}$ - Oleopalmitic acid; C18:0 Stearic acid; C18:1 $\Delta^{9}$-Oleic acid; C18:1 $\Delta^{7}$ - Octadecenic acid; C18:2 $\Delta^{9} . \Delta^{12}$ - Linoleic acid; C20:0 Arachidic acid; C18:3 $\Delta^{9} . \Delta^{12} . \Delta^{15}$ - $\alpha$-linolenic acid; C20:1 $\Delta^{3}$ Eicosenic acid; C22:0 Behenic acid; C22:1 $\Delta^{13}$ - Erucic acid; C24:0 Lignoceric acid; SFA saturated fatty acids; MUFA monounsaturated fatty acids; PUFA polyunsaturated fatty acids; SAT/UNSAT saturated/unsaturated fatty acids.

in Olea europaea (about 12\%) (Dubois et al., 2007) and it is comparable with the content observed in the Oenothera genus (Krzaczek et al., 1995).

The $\alpha$-linolenic acid, found in the fruits of all studied species, is a predominant component of the fatty acid fraction in C. elata (32.44\%) and in $C$. otrubae (31.93\%). The lowest amounts were observed in C. pseudocyperus (0.51\%). For comparison purposes, in the fruits of Olea europaea, only $0.6 \%$ of this acid was found (Dubois et al., 2007) (i.e. about 50 times lower content than in C. elata and C. otrubae).

Among the isolated and identified MUFA, oleic acid was the most abundant. It is found in all the studied taxa ranging from $11.5 \%$ in $C$. flava to $42.5 \%$ in $C$. vulpina. The presence of other unsaturated acids was found (oleopalmitic n-9, oleopalmitic n-7, octadecenic and eicosenoic), but these acids occur in significantly smaller amounts. In the studied species there was also a small amount of erucic acid, whose concentration is generally lower in species belonging to the Carex subgenus (Tables 1, 2).

The highest percent value of unsaturated fatty acids is observed in C. pseudocyperus (92.18\%). The remaining species have lower concentration of these acids (62.98\%-89.3\%) (Tables 1, 2).

As commented, C. pseudocyperus has a high content of unsaturated fatty acids (particularly linoleic acid $-72.61 \%$ ), but is also characterized by the lowest level of $\alpha$-linolenic acid $(0.51 \%)$. Such a situation also refers to other species. The dominating unsaturated fatty acids divide the analyzed group into two subgroups. The first one, with 4 species (C. flava, C. pseudocyperus, $C$. riparia and $C$. leporina), is a good source of linoleic acid and the second subgroup, including the remaining species, is a good source of $\alpha$-linolenic acid. Also for oleic acid, C. vulpina can be regarded as the best raw material.

A greater content of linoleic acid characterizes the species from the Carex subgenus, and $\alpha$-linolenic and oleic acids from the Vignea subgenus.

Our analyses have also shown the presence of saturated acids in the studied samples, where palmitic acid is the predominant one. The remaining saturated fatty acids, which were not found in all the studied species, occur in comparatively low concentrations (usually not exceeding $2 \%$ ) (Tables 1, 2).

Our results agree with those reported for other sedge species: C. carsei, C. solandri, C. fedia, C. flava, C. pendula and C. dioica (Lotti and Averna, 1969; Morice, 1977; Ahmad and Ansari, 1987). The especially visible similarity concerning the saturated acids group is the domination linoleic acid and a significant differentiation of the $\alpha$-linolenic acid 


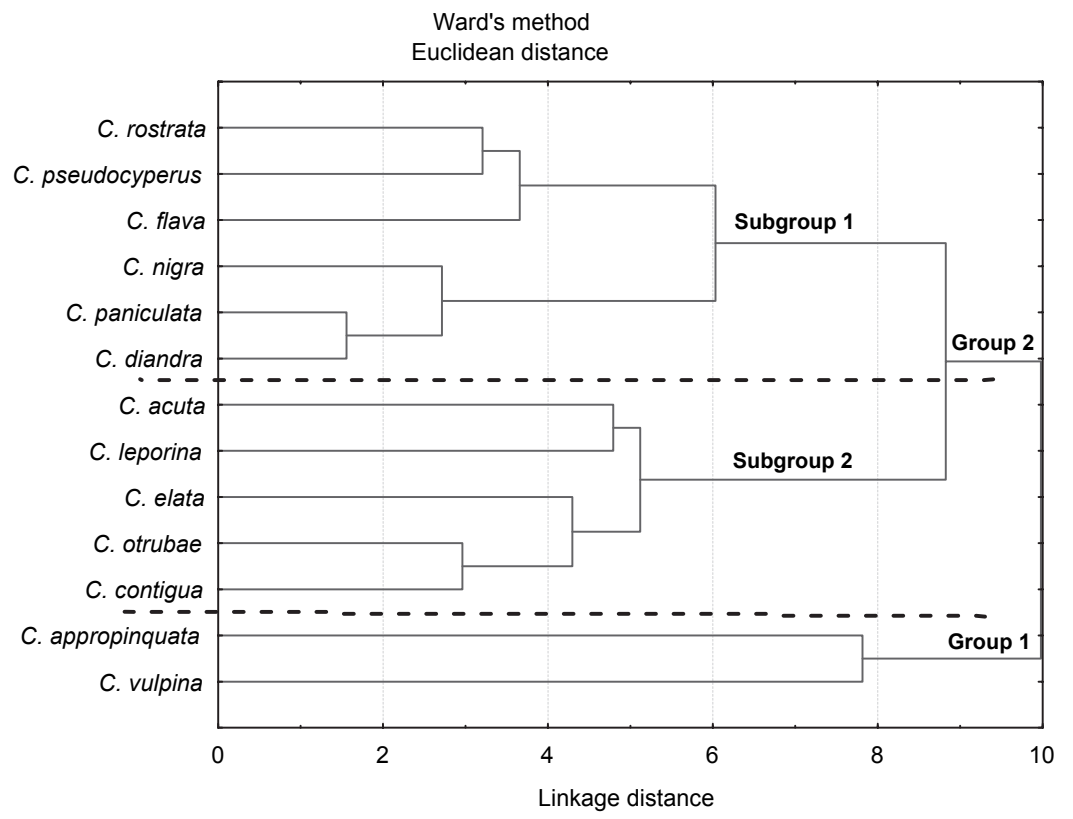

Figure 1.

Dendrogram of cluster analysis of fatty acid compositions of 13 species of Carex based on all identifying fatty acids. The clustering was made using Ward's method of agglomeration with Euclidean distance.

concentration in sedges. The results of our study and the literature data show that the studied sedges can be divided into two distinct groups: one with a concentration of $\alpha$-linolenic acid oscillating within the limits from ten-plus to several tens percent and another, varying from slightly more than 0 to almost 2.2 percent. The confirmed feature concerning the group of saturated acids is the domination of the palmitic acid and the concentrations of the remaining saturated acids, which were similar to those presented in the literature data. Most likely, one can believe that such a composition of fatty acids and their mutual proportions are characteristic of the representatives of the Carex genus.

Similar studies on the fruits of Cyperus esculentus (Cyperaceae) have been carried out by Kapseu et. al (1997). The fruits of $C$. esculentus are characterized by definitely worse parameters of the fatty acid composition than the studied Carex species. In addition, in C. esculentus, a distinct domination of saturated fatty acids was found, particularly stearic acid.

The percentages of fatty oil fractions in the fruits of studied sedges are varying. The lowest content was observed in C. pseudocyperus $(3.73 \%)$ and the highest in C. leporina $(46.52 \%)$ (Tables 1,2$)$. In the remaining species these values oscillated within two intervals. The first interval $(10-15 \%$ oil content) agrees with the one reported by earlier authors (Earle and Jones, 1962; Jones and Earle, 1966; Morice, 1977; Ahmad and Ansari, 1987) on other sedge species or organs (Ayaz and Olgun, 2000). The importance of the species from the Cyperaceae family as a significant source of oil is confirmed by athe results of studies made on Cyperus esculentus tubers by Eteshola and Oraedu
(1996). According to these authors the tubers can contain up to $27 \%$ oil.

A dendrogram was obtained after the analysis of similarity based on the profile of fatty acid composition. The obtained dendrogram (Fig. 1) shows a division of the Carex species into two groups: the first one included $C$. appropinquata and $C$. vulpina, distinguished by the highest level of palmitic acid, but having no close habitat connections; the second group, including the remaining species, can be additionally divided into two subgroups. The species belonging to the first of the subgroups is characterized by a higher level of linoleic acid and a lower level of $\alpha$-linolenic acid than the taxa from second one. This subgroup includes only species from very moist or medium moist habitats. It refers particularly to the agglomeration of $C$. rostrata, C. pseudocyperus, $C$. flava and $C$. nigra, and the agglomeration of $C$. paniculata and $C$. diandra. In both cases, the listed species grow in very similar habitat conditions. A majority of the species in the described subgroup includes representatives from the Carex subgenus. The second of the determined subgroups, except for $C$. acuta, contains species growing in more dry habitats. In this subgroup, all taxa, except for $C$. acuta and $C$. elata belong to the Vignea subgenus.

Based on our results, the fruits of the studied species of the genus Carex can be considered as plant raw material with a relatively high content of unsaturated fatty acids, both polyunsaturated such as linoleic and $\alpha$-linolenic and monounsaturated such oleic acids. Comparing the obtained results to data referring to other species of plants widely applied in prophylaxis and therapy, we can infer that oil from sedge nutlets is a very good source of PUFA. 
Table 2

Percentage contents of fatty acids obtained from fruits of Carex L. from the Vignea subgenus

\begin{tabular}{|c|c|c|c|c|c|c|c|}
\hline Fatty acid & C. paniculata & C. appropinquata & C. diandra & C. vulpina & C. otrubae & C. contigua & C. leporina \\
\hline C14:0 & $0.12 \pm 0.010$ & $2.11 \pm 0.100$ & $0.28 \pm 0.010$ & $0.18 \pm 0.020$ & $0.26 \pm 0.030$ & $0.14 \pm 0.030$ & $0.62 \pm 0.003$ \\
\hline C16:0 & $7.42 \pm 1.032$ & $20.63 \pm 0.199$ & $9.83 \pm 0.098$ & $15.08 \pm 0.099$ & $6.68 \pm 0.760$ & $6.07 \pm 0.065$ & $8.20 \pm 0.100$ \\
\hline C16:1; $\Delta^{9}$ & $0.05 \pm 0.001$ & $0.05 \pm 0.002$ & $0.07 \pm 0.001$ & $0.20 \pm 0.007$ & $0.23 \pm 0.024$ & $0.06 \pm 0.002$ & $0.20 \pm 0.045$ \\
\hline$C 16: 1 ; \Delta^{7}$ & $0.07 \pm 0.002$ & $0.28 \pm 0.008$ & $0.06 \pm 0.001$ & $0.25 \pm 0.007$ & $0.18 \pm 0.002$ & $0.20 \pm 0.010$ & $0.13 \pm 0.033$ \\
\hline C18:0 & $3.22 \pm 0.098$ & $2.74 \pm 0.099$ & $3.64 \pm 0.043$ & $1.49 \pm 0.010$ & $1.98 \pm 0.020$ & $1.77 \pm 0.049$ & $1.87 \pm 0.040$ \\
\hline C18:1; $\Delta^{9}$ & $20.51 \pm 1.001$ & $14.02 \pm 0.800$ & $19.83 \pm 0.989$ & $42.50 \pm 0.998$ & $20.37 \pm 0.101$ & $19.13 \pm 0.890$ & $12.33 \pm 0.099$ \\
\hline $\mathrm{C} 18: 1 ; \Delta^{7}$ & $0.67 \pm 0.122$ & 0 & $0.54 \pm 0.154$ & 0 & $0.81 \pm 0.009$ & $0.97 \pm 0.010$ & $0.64 \pm 0.079$ \\
\hline $\mathrm{C} 18: 2 ; \Delta^{9} \cdot \Delta^{12}$ & $48.79 \pm 2.000$ & $33.50 \pm 0.099$ & $45.39 \pm 0.760$ & $33.61 \pm 1.002$ & $28.89 \pm 0.350$ & $39.64 \pm 0.450$ & $64.87 \pm 0.980$ \\
\hline C20:0 & $0.50 \pm 0.009$ & $0.32 \pm 0.003$ & $0.55 \pm 0.050$ & $0.29 \pm 0.007$ & $1.12 \pm 0.033$ & $0.75 \pm 0.009$ & $0.77 \pm 0.009$ \\
\hline $\mathrm{C} 18: 3 ; \Delta^{9} \cdot \Delta^{12} \cdot \Delta^{15}$ & $16.04 \pm 0.670$ & $13.39 \pm 0.100$ & $17.09 \pm 0.323$ & $1.08 \pm 0.009$ & $31.93 \pm 0.100$ & $26.19 \pm 0.340$ & $3.23 \pm 0.003$ \\
\hline $\mathrm{C} 20: 1 ; \Delta^{3}$ & $0.27 \pm 0.010$ & $0.14 \pm 0.009$ & $0.20 \pm 0.001$ & $0.74 \pm 0.007$ & $0.32 \pm 0.020$ & $0.27 \pm 0.060$ & $0.28 \pm 0.003$ \\
\hline $\mathrm{C} 22: 0$ & $0.44 \pm 0.070$ & 0 & 0 & 0 & $1.01 \pm 0.009$ & $0.46 \pm 0.034$ & $0.07 \pm 0.001$ \\
\hline $\mathrm{C} 22: 1 ; \Delta^{13}$ & $0.19 \pm 0.023$ & $1.60 \pm 0.087$ & $0.41 \pm 0.021$ & $0.20 \pm 0.004$ & $0.16 \pm 0.009$ & $0.38 \pm 0.020$ & $1.12 \pm 0.024$ \\
\hline $\mathrm{C} 24: 0$ & $0.31 \pm 0.008$ & $0.94 \pm 0.005$ & $0.18 \pm 0.009$ & $0.23 \pm 0.001$ & $0.70 \pm 0.012$ & $0.36 \pm 0.008$ & $0.68 \pm 0.009$ \\
\hline SFA & $12.01 \pm 0.205$ & $26.74 \pm 0.081$ & $14.48 \pm 0.042$ & $17.27 \pm 0.027$ & $11.75 \pm 0.144$ & $9.95 \pm 0.033$ & $12.21 \pm 0.027$ \\
\hline MUFA & $21.76 \pm 0.193$ & $16.09 \pm 0.181$ & $21.29 \pm 0.194$ & $44.12 \pm 0.205$ & $22.07 \pm 0.028$ & $21.01 \pm 0.165$ & $14.7 \pm 0.047$ \\
\hline PUFA & $64.83 \pm 1.335$ & $46.89 \pm 0.100$ & $62.48 \pm 0.542$ & $34.69 \pm 0.505$ & $60.82 \pm 0.225$ & $65.83 \pm .395$ & $68.1 \pm 0.492$ \\
\hline MUFA+PUFA & $86.59 \pm 0.479$ & $62.98 \pm 0.215$ & $83.77 \pm 0.281$ & $78.81 \pm 0.291$ & $82.89 \pm 0.077$ & $86.84 \pm 0.223$ & $82.27 \pm 0.158$ \\
\hline SAT/UNSAT & 0.13 & 0.42 & 0.17 & 0.21 & 0.14 & 0.11 & 0.14 \\
\hline C18:1; $\Delta^{9} / \mathrm{C} 18: 2 ; \Delta^{9} \cdot \Delta^{12}$ & 0.42 & 0.41 & 0.43 & 1.26 & 0.7 & 0.48 & 0.19 \\
\hline Mass of samples $(\mathrm{g})$ & 17.46 & 3.6 & 10.3 & 3.6 & 9.6 & 9.2 & 2.3 \\
\hline Quantity of oil (g) & 1.64 & 1.1 & 3.58 & 1.6 & 1.52 & 1.37 & 1.07 \\
\hline $\begin{array}{l}\text { Percentage } \\
\text { contents of oil }\end{array}$ & 9.39 & 30.55 & 34.75 & 44.44 & 15.83 & 14.89 & 46.52 \\
\hline
\end{tabular}

\section{REFERENCES}

Ahmad SM, Ansari MH. 1987. Studies on minor seeds oils. Fett. Wiss. Technol. 89, 154-156.

Ayaz FA, Olgun A. 2000. Fatty acid composition in leaf lipids of some Carex L. species from Northeast Anatolia (Turkey). Grasas y Aceites 51, 307-310.

Barclay AS, Earle FR. 1974: Chemical analysis of seeds III. Oil and protein contents of 1253 species. 28, 178-236.

Bogucka-Kocka A, Krzaczek T. 2004. 2D-TLC and RP. HPLC analysis of phenolic acids in some Carex species. Her. Pol. 50, 3/4, 12-16.

Catling PM., Mcelroy AR, Spicer KW. 1994 Potential forage value of some eastern Canadian sedges (Cyperaceae: Carex). J. Range Manag. 47, 226-230.

Dubois V, Breton S, Linder M, Fanni J, Parmentier M. 2007. Fatty acid profiles of 80 vegetable oils with regard to their nutritional potential. Eur. J. Lipid. Sci. Technol. 109, 710-732.

Earle FR, Jones Q. 1962. Analysis of seed samples from 113 plant families. Econ. Bot. 16, 221-250.

Egorova TV. 1999. Osoki (Carex L.) Rosiji i sopriedielnych gosudarstw. Sankt-Peterburskaja Gosudarstw. Chimiko-Farm. Akademia, Sankt Petersburg.

Eteshola E, Oraedu ACI. 1996. Fatty acid composition of tigernut tubers (Cyperus esculentus L.), baobab seeds (Adansonia digitata L.), and their mixture. J. Amer. Oil Chem. Soc. 73, 2, 255-257.

Fox JL. 1991. Forage quality of Carex macroachaeta emerging from Alaskan alpine snowbanks trough the summer. Amer. Midl. Natur. 126, 282-293.

Grzelak M, Janyszek M, Spychalski W. 2005. Evaluation of fodder value of the over ground parts of sedges from the section Muehlenbergianae (L.H. Bailey) Kük. Bot. Steciana. 9, 89-95.
Hegnauer R: Chemotaxonomie der Pflanzen. 1963. Bd II, Birkhüser Verlag, Basel und Stuttgart.

Hegnauer R: Chemotaxonomie der Pflanzen. 1986. Bd VII, Birkhüser Verlag, Basel und Stuttgart.

Herman FJ. 170. Manual of the Carices of the Rocky Mountains and Colorado Basin. Agricultural Handbook. 374, USDA.

Ingvason PA. 1969. The golden sedges of Iceland. World Crops. 21, 218-220.

Janyszek M, Grzelak M, Spychalski W. 2005. Nutritive value of over ground parts of sedges from the Vulpinae (Carey) Christ. section at different plant developmental stages. Bot Steciana. 9, 103-109.

Janyszek M, Jagodziński AM, Janyszek S, WrońskaPilarek D. 2008. Morphological variability of Carex spicata Huds. utricles among plant communities. Flora 2008, 203, 386-395.

Janyszek M, Jagodziński A.M. 2009. Variability of perigynium morphology of Central European members of Carex sect. Phaestoglochin (Cyperaceae) from variable plant communities. Pl. Syst. Evol. 278, 87-99.

Jones Q, Earle FR. 1966. Chemical analyses of seeds II: oil and protein contents of 759 species. Econ. Bot. 20, 127-155.

Kapseu C, Mbofung CMF, Kayem GJ. 1997. Fatty acids and triglycerides of fruit oils from Cyperus esculentus and Balanites aegyptiaca. Scien. des Alim. 17, 531-537.

Kawabata J, Ihikawa S, Kurihara H, Mizutani J. 1989. Kobophenol A, a uniqe tetrastilbene from Carex kobomugi Owi. (Cyperaceae). Tetrahed. Lett. 30, 3785-3788.

Kawabata J, Mishima M, Kurihara H, Mizutani J. 1991. Kobophenol B, a tetrastilbene from Carex pumila. Phytochem. 30, 645-647. 
Krzaczek T, Bogucka-Kocka A, Śnieżko R. 1995 The analysis of fatty acids in oil from some species of Oenothera. Acta Pol. Pharm. 52, 429-430.

Kukkonen I. 1971. Flavonoid chemistry of the Cyperaceae. A preliminary survey. Mitt. Bot. Staat. 10, 622-638.

Kurihara $\mathrm{H}$, Kawabata J, Ihikawa S, Mishima M, Mizutani J. 1990. (-)-ع-Viniferin and Related Oligostilbenes from Carex pumila Thunb. Agric. Biol. Chem. 54, 1097-1099.

Kurihara H, Kawabata J, Ihikawa S, Mishima M, Mizutani J. 1991. Oligostilbenes from Carex kobomugi. Phytochem. 30, 649-653.

Li CY. 1974. Phenolic compounds in understory species of alder, conifer, and mixed alder conifer stands of coastal Oregon. Lloydia. 37, 603-607.
Lotti G, Averna V. 1969. Carex flava, Carex pendula. Riv. Ital. Sost. Grasse. 46, 668.

Manhart JR. 1986. Foliar flavonoids of the North American members of the Carex section Laxiflorae (Cyperaceae). Biochem. Syst. Ecol. 14, 85-90.

Morice I,M. 1977. Seed fats of some New Zealand Cyperaceae. Phytochem. 16, 571-574.

Suzuki K, Schmizu T, Kawabata J, Mizutani J. 1987. New 3,5,4'-trihydroxystilbene (resveratrol) oligomers from Carex fedia Nees var. miyabei (Franchet) T. Koyama (Cyperaceae). Agric. Biol. Chem. 51 (4), 1003-1008.

Recibido: 20/7/09 Aceptado: 19/10/09 